\title{
International Dependency and the Economic Development of Less Advanced Countries
}

\author{
Saidou Baba Oumar ${ }^{1} \&$ Molem Christopher Sama ${ }^{1}$ \\ ${ }^{1}$ Department of Economics \& Management, University of Buea, Buea, Cameroon \\ Correspondence: Saidou Baba Oumar, Department of Economics \& Management, University of Buea, Buea, \\ Cameroon. E-mail: saidoubo@gmail.com
}

Received: February 14, 2015

Accepted: April 25, 2015

Online Published: May 25, 2015

doi:10.5539/ibr.v8n6p117

URL: http://dx.doi.org/10.5539/ibr.v8n6p117

\begin{abstract}
Dependency is a double-edge sword that can either promote or demote the status of the dependent. The case of the dependency relationship between less advanced countries (LACs) and most industrialized countries (MICs) is a pertinent example that explains the attitude developed by each party to situate and maintain itself in its current status to be classified as underdeveloped, developing or developed. This paper investigated the effects of international dependency on the economic development of LACs using the analytical approach of secondary data interpretation and found that although the dependency between LACs and MICs is bi-directional, LACs have surrendered all their potentials for attaining economic development to MICs who are steadily designing different devices such as developmental projects aids, structural adjustment programs, MDGs or good governance programs to maintain them in a state of economic and political vulnerability. In view of this, the paper recommends LACs to wake up from sleep and take their destiny in hand by building up strong institutions that can take care of their needed structural changes and basic-needs requirements before embracing the ideas of international dependence revolution models (IDRMs) and market fundamentalism models (MFMs), for no external forces may sacrifice to hold the bull by the horns for them to milk the cow.
\end{abstract}

Keywords: trade, growth, government, market, resources, vulnerability

\section{Introduction}

Dependency involves some sort of reliance of an economic agent on another through which the power of the dependent party is reinforced or weakened owing to its ability or inability to take advantage of the dependence relationship. In other words, it is a double-edge sword that can promote or demote the status of the dependent and can assume a social, political, technological, local, an international or economic dimension. The dependency phenomenon between less advanced countries (LACs) and most industrialized countries (MICs) can be traced back to the era of colonization when colonialists launched the race for the exploration of new horizons and exploitation of reservoirs of natural resources that can fuel their industries and economic progress. This initiative invoked the ardent desire to condition the future of LACs to embrace and accept the models from MICs as the only alternatives to success. As a result, societal norms and values, political ideologies, technological experiences and models of economic development from MICs were copied and indirectly or directly replicated in LACs without a proper scrutiny of local realities. Gradually, the texture of the society in LACs is modified and transformed from all aspects to respond to the exigencies of MICs. For instance, the weight of traditional beliefs, communal system of administration, use of archaic technology in production processes, and barter system of exchange eroded in favor of instruments of modernity suggested by MICs. Thus, coins and currency note are now used in undertaking economic transactions between people and countries at large because of the inherent features they possess over gold and silver and other precious metals.

Today, international finance is organized through the intermingling of nations' central banks policies and managed by two main international financial institutions-the International Monetary Fund (IMF) and World Bank (WB). LACs and MICs of the world assume some links with these two institutions. And as countries are not self-sufficient to live in isolation and produce all of what they need to consume, some economic relationships between them through international trade become necessary and unavoidable. International trade, which calls for international finance operations, strongly depends on the Ricardo (1817)'s principle of comparative advantage between countries, which stipulates that countries that are heavily abundant in capital resources should enter into 
trading with those extremely endowed with land where agricultural products are produced at less expensive costs, in order to boost world output growth and living standards of people. This flow of goods and services from one end to the other necessitates the transfer of funds in terms of countries' domestic currencies within the framework of international finance. Though domestic currencies vary from one country to another, however, there exists a tight relationship between them in terms of pegging to a reference currency such as the United States Dollar (US\$) or a basket of currencies say the Australian Dollar (AU\$), Canadian Dollar (CA\$), Japanese Yen (¥), Pound Sterling (£), Euro $(€)$, Saudi Arabian Riyal (SAR), or Swiss Franc (SF). Owing to this link between currencies of the world, any positive or negative developments occurring in one country have high probability of spread to other countries through the distributive factor of economic transactions such that imported inflationary pressures in one country or general shocks in business transactions between some countries, for instance, may end up affecting the economy of the entire world as was observed with the petroleum oil shocks of mid-1980s.

Independent viewpoints in relation to world economic transactions have provided an understanding of the dynamism and performance of the world economy from time to time. Hamada (1974) pointed out that the recent succession of international financial crisis from the collapse of the gold standard exchange has pushed countries to resort to a choice between the application of either fixed or flexible exchange rate to run their economic transactions across the world or the combination of the two at the same time to support their economies. However, the traditional question of the independence of national economic policies appeals to the Keynesian macroeconomic model which fixes the price level and allows real income to vary in response to national monetary or fiscal policies. Within the same line of thinking, the author disclosed that the choice between either of the two policies is a function of one's interpretation of the economic relations about whether the Phillips curve and the normal rate of unemployment appears significant as a yardstick for the assessment of an economy or the frictional or structural aspect of unemployment more precise and convenient for that matter. In the author's point of view, fiscal models seem more adequate to handle economic problems and disturbances in an open economy with full-employment conditions.

Yet in a historical perspective, Bird (1978) portrayed IMF as the world stabilizing organization on financial matters between LACs from 1945 to late 1970s. From its first ages, the fund considered the problem of economic development of LACs as being out of its scope of operation. LACs had to struggle in solving both their economic and socio-political problems which later on led to a continuous dependency following their accession to political independence in the 1960s. From 1950-1960 the fund incorporated the objectives of aiding to the economic development of LACs among its priorities and started working towards that aim. Unfortunately, the brutal and sudden changes that overtook the events in 1970s with the attendant complications from the collapse of the Bretton Woods international monetary system changed the pattern of IMF operations, thus pressing LACs to now request for a new international economic order. But for Levitt (1989), the existing economic relations and transactions between LACs and MICs condition LACs to a situation of extreme dependence on foreign exchange that pushed them to borrow from IMF and draw structural adjustment loans (SLAs) from WB programs due to their inability to perform well in food provision in 1970s-which was accompanied by a fall in exports volumes that led to deteriorating terms of trade. This phenomenon which continued till 1980s brought about 15\% fall in imports volume between 1982 and 1985 in low incomes countries (LICs) of Africa.

For the operation of the world economy is influenced by the degree of dependency between countries, the purchasing power parity of domestic currencies and the resources endowment base of countries have a significant role to play in determining the status of a country as advanced or less advanced in relation to other countries. Based on this dependency relation, it is assumed that the principle of comparative advantage offers a golden opportunity on which countries that are heavily endowed with natural resources can capitalize to achieve a sustainable long run economic development. Unexpectedly, the reverse is observed as the MICs which are heavily dependent on the natural resources of LACs are the ones taking advantage of the situation to sustain a long run economic development owing to their ability to exert some economic powers on the economies of LACs. As a corollary to this state of affairs, it is often noticed that the three main indicators of economic development such as poverty rate, unemployment rate, and income inequality have all been on the increase in LACs despite the achievement of some annual increase in the growth rate of the national income (NI) or gross domestic product (GDP) in some countries like Nigeria, Cameroon, and Brazil in 1970s and 1980s. This paradox of poverty of people in the midst of plenty in LACs raises a series of questions that calls for investigation, hence the significance of this paper. Therefore the main objective of this paper is to examine the effects of international dependency on the economic development of LACs. Specifically, the paper envisages addressing the followings 
aspects of the subject matter.

- To understand the trade linkages between LACs and MICs;

- To examine the financial ties framework and causes of balance of payments disequilibria of LACs;

- To analyze the socio-economic development indicators of LACs and MICs;

- To appreciate the effects of dependency on the economic development of LACs; and

- To offer recommendations towards promoting LACs' economic development.

The rest of the paper is structured as follows. Section 2 reviews the literature on economic development theories; section 3 explains the methodology used to address the objectives of the paper. Section 4 covers the data analysis and discussion of results, while section 5 provides the conclusion and recommendations of the paper.

\section{Review of Economic Development Theories}

Economic development theories evolved from the pre-classical (1500s-1775) through classical (1776-1780s), neo-classical (1780s-1930s), Keynesian economics (1930s-1970s), development economics (1940s-1980s), neo-liberalism (1990s) to the millennium development goals agenda [MDGs] (1990s-2015) period. From this evolution process, economic development denoted: therapy for progress, accumulation of wealth, control over resources, industrialization, economic growth, political and social modernization, human prosperity and enlargement of people's choices, globalization via deregulation and liberalization, and structural reforms to enhance the welfare of mankind (Pieterse, 2010, p. 7), thus making the concept to be interchangeably used to mean economic growth and development in the past. The flexibility in the use of the concept led to the fashioning of several terms for its measurement and the classification of countries into groups. As a result, countries are categorized into (i) first, second, or third world; (ii) less developed, developing, or developed; (iii) backward, middle, or advanced; (iv) low income, middle income, or high income; (v) less industrialized, emerging, or most industrialized; (vi) poor, transitory, or rich; and (vii) highly indebted poor, averagely indebted, or marginally indebted.

Whichever perspective is considered, the bottom line remains that economic development is a relative phenomenon and can only be achieved if and only if the society has the ability to meet the essentials of life (food, shelter, education, protection...); self-esteem (feeling a sense of being a person worthy of self-respect and spared from being used as a tool by others for their own interests); and enjoys freedom from dependence and servitude (feeling free from material alienation and social servitude to nature, people, oppression, misery, fatality)-the three core values of development. And these three core values can only be attained through a substantial reduction of at least two of the three main problems of the society: poverty, unemployment, and unequal income distribution, which constitute the substance of the concept of economic development. In essence economic development is obtained when the society experiences an economic condition of considerable reduction in unequal distribution of income, the rates of poverty and unemployment or in at least two of the three social vices. As for economic growth, it is an economic condition of mere annual increase of at least 5\% in GDP of an economy, which may not necessarily trickle down to the poor in the society. And with regard to development, it is just an expansionary phenomenon that takes place in a person, family or an area as a result of invisible or visible activities. Yet it should be noted that economic growth is necessary for the achievement of economic development. But in general, all theories of economic growth and economic development that evolved across time attempt to explain how and why economic development happens in some places and stagnates in others. Thirlwall (1999), Todaro and Smith (2009), and Pieterse (2010) offered a chronological exposé of these theories to ease the understanding of their contextual evolution over time.

\subsection{Economic Development Theories of the Period 1500s-1940s}

The first attempt to associate the activities of man to economic development dates back to mercantilism which dominated the period 1500s to 1775 . The mercantilist school of thought or trade restriction model (TRM) of economic development perceived economic prosperity as the achievement of balance of trade through trade monopolies, protection of the domestic economy by tariffs and preferential laws, exchange in bullions (gold and silver), colonization to gain control over raw materials for the fuelling of the European industrial revolution industries that liberated Europe from the feudal society bondage. Prominent among mercantilist writers are Mun (1621, 1664), Steuart (1767), and de Monchrétien (1891). Yet despite the emancipation the school brought to the society, it limited output growth and the welfare of the society as only few individuals were receiving the benefits of the trade at the expense of the majority. 
At the dusk of 1775, TRM started receiving heavy criticisms. Smith (1776) proposed the free trade model (FTM) of economic development as an alternative to it. FTM dominated the period 1776 to 1780 s and advocated for trade without barriers, division of labor and specialization, limited government intervention, and competition to enhance the production of goods and services for better standards of living in the society. However, over time, the ideals of the model led to human obsession that created a fundamental problem of disproportion between available resources and the mouths to feed on them in the society. Worried about this situation, Malthus (1798) put forward the resources constraint model (RCM) of economic development which stressed that future human progress is threatened by human passion as the world population increases in geometric series, while food production increases in arithmetic sequence. The argument of RCM held substance from 1780s to 1790s after which the society regained hope with the comparative advantage model (CAM) of economic development of Ricardo (1817) and the laissez-faire model (LFM) of Jevons (1871), Marshall (1890), Walras (1899), and Menger (1976) who perceive market mechanisms and minimal state intervention in the economy as the best option for efficient and effective allocation of resources among competing economic agents (markets assumed to be perfect, prices assumed to adjust automatically through the inter-play of demand and supply, consumers assumed to be sovereign and economic agents assumed to be motivated by self-interest in decision making) until when the world economy was trapped into the great depression in 1929 before recognizing the limitations of the market forces to adjust automatically in the long run and the important role the state can play in stabilizing the economy against unwanted economic situations that can besiege the economy at any time due to uncertainty through the enforcement of fiscal or monetary policies as advocated by the Keynesian economics model (KEM) of Keynes (1936).

\subsection{Economic Development Theories of the Period 1940s-1980s}

The period 1940s-1980s was dominated by the linear stages models (LSM) of economic growth such as the Harrod-Domar model (HDM) of economic growth and Rostow's stages model (RSM) of economic growth, and the structural change models (SCM) of economic growth such as the Lewis' theory of economic development (LTD) and patterns of development empirical analysis (PDA) of Chenery and his associates. These models perceived economic growth as a sequence of successive stages through which all economies must pass in order to grow. The main assumption of the theories is that the accumulation of the right amount and combination of savings, investments, foreign aids and the appropriate polices were the necessary components to trigger economic development. This was experienced by contemporary MICs.

Developed independently by Harrod (1939) and Domar (1947), HDM explains the mechanism by which more investments accelerate the rate of economic growth in an economy. The model is often referred to as the AK model for it is based on a linear production function in which the output is given as the stock of capital $\mathrm{K}$ multiplied by a constant A. It maintains that the more new investments corresponding to net additions to the stock of capital are injected in an economy, the more the GDP (output, production) of the economy grows by the level of net additions to the stock of capital. The merits of the model rest on its simplicity in terms of description and prediction if one has a target for output growth. Yet its major limitations are the lack of empirical evidence, lack of robust relationship between investment rate and growth rate and overestimation of the quantitative role of investment.

Fashioned by Rostow (1960), RSM was influenced by the 15th to 18th century experience of European societies. The theory maintains that transition from underdevelopment to economic development passes through five stages which every economy must experience. At the traditional society stage the economy is characterized by rural and agricultural, low productivity and rudimentary techniques, subsistence expenditure with no savings and investments, and conservative attitudes of people. By the transitional or precondition for take-off stage, the economy opens up to trade transactions and techniques, establishment of banks and use of currency as medium of exchange, attitudes of people evolve and savings economy is embraced. At the critical take-off or self-sustained growth stage, the economy engages in increased savings and investments, overcomes obstacles to industrialization generally through revolution over a period of 50 to 100 years before transiting to the fourth stage. By the drive to maturity stage, the economy achieves larger diffusion of innovation and diversification, leading sectors of economic activities start leveling off and lagging sectors begin catching up, rates of poverty are substantially reduced and standards of living are rising in the economy. Finally by the era of high mass consumption, the economy reaches an age in which consumers concentrate more on manufactured durables, luxuries and the economy focuses attention on issues of defense and security, equality and welfare rather than subsistence concerns. A careful examination of the features of the model reveals that it is an investment-led take-off approach to economic development. As a result, development can halt at the take-off stage if savings is lacking. Therefore, there is a serious need to fill any existing financing gap in the economy to avoid this trap 
through external aids or loans. The followings are some of the limitations of the model. One, the model is inspired by trends of events and realities of Western Europe economies and is not applicable to the different and varied context of LACs that are mostly within the first and second stages. Two, it lacks predictive use for no specific timeframes are ascribed to its different stages. Three, it gives no details about the pre-conditions stage for economic growth, and four, in the absence of the necessary structural, institutional and attitudinal requirements as is the case for LACs, the accumulation of savings and investments will not accelerate economic growth rate.

SCMs place emphasis on the ways and means that can enable the transformation of LACs from a heavily dependent agricultural economy to a more modern, urbanized, industrialized and varied manufacturing and service economy using the neo-classical market mechanism tools. The seminal two-sector surplus-labor model of economic development or LTD by Lewis (1954) was expanded later on by Ranis and Fei (1961), Jorgenson (1961), and Fei and Ranis (1964) to become the general theory of economic development in surplus-labor LACs between 1960 and 1970. The model holds that dualism is the main feature dominating the economy of LACs where a high productivity modern industrial sector (thousands of workers) coexists with a traditional overpopulated rural subsistence sector (millions of workers). Given the over-population of workers in the rural subsistence sector, surplus of labor (no competition for labor) results in the traditional agricultural sector with zero marginal productivity of labor $\left(\mathrm{MP}_{\mathrm{L}}=0, \mathrm{TP}=\right.$ maximum $)$ where all rural workers receive equal wages $\left(\mathrm{TP}_{\mathrm{A}}\right.$ $\div \mathrm{Q}_{\mathrm{LA}}=\mathrm{W}_{\mathrm{A}}$ ). Against this background the economic development process can be initiated through a progressive transfer of the surplus labor from the agricultural sector to increase output and create employment in the industrial sector proportionately with the rate of industrial investment and capital accumulation in the industrial sector where there is competition for labor, wages are constant but greater than wages in the agricultural sector; until the labor surplus is eliminated in the traditional sector and adequately accommodated in the modern sector of the economy where capital stock is allowed to increase due to reinvestment of all profits. Despite the surplus labor transfer opportunity from a heavily endowed sector to a needy one, the model is not free from shortcomings. For instance, the rate of transfer of labor and employment generation in the modern sector is not proportional to the rate of modern sector capital accumulation because capital accumulation can also mean labor-saving technology through the use of more advanced labor-saving capital equipments technology from abroad in the production process by employers rather than reinvesting all profits in the local economy, hence the flight of capital. Also the assumption of surplus labor existence in the agricultural sector and full employment in the modern sector is invalid in the sense that some people in the modern sector may not be aware of availability of job opportunities and will remain unemployed, while on the other hand many workers are deserting the agricultural sector in search of white collar jobs in urban centers. Furthermore, wages in the modern industrial sector are not constant but they tend to increase due to pressures from trade unions. Finally, output in the industrial sector grows substantially but incomes and level of employment for rural workers remain unchanged with the lion share of the production process going to the capitalists, thereby leading to what may be called "anti-developmental economic growth".

PDA of Chenery(1960), Chenery and Taylor (1968), and Chenery and Syrquin (1975) focuses on a series of economic, industrial and structural process which a LAC must undergo over time in order to transform from a traditional agricultural economy to a modern industrial one. Unlike LTD, the model of PAD identifies increased savings and investments as necessary but not sufficient conditions for economic growth. The model acknowledges the role of physical and human capital accumulation but emphasizes a fundamental change in the methods of production (from agricultural rudimentary to modern sophisticated methods), composition of consumer demands (from basic foods to diverse manufactured goods and services), international trade environment (from unfair to fair rules of the game), use of resources (from unsustainable to sustainable use), urbanization trend (growth of cities via rural-urban migration and expansion of urban industries), growth and distribution of the population (decline in size of family, decrease in overall population estimates and spread of population across regions) in the developing economy. Therefore, there is the need for a set of domestic and international policies to enforce the changes that bring about the self-sustained economic growth of the economy. Using the available physical and human capital with combined appropriate domestic and international policies, the required structural changes in LACs will be achieved. Consequently, the economy will grow from the state of underdevelopment to that of development as desired. In general, the model ascribes the underdevelopment condition of LACs to internal as well as external constraints. The internal constraints may include limited natural resource endowment, overpopulation, inefficient institutions and ill-though macro-economic policy objectives. Conversely, the external constraints include restriction to participate in international trade dynamics (imports, exports), limited access to advanced technology and stringent conditions for access to external capital (development assistance and aid programs). In fact, the model retains external constraints as the main hindrance 
to the development of LACs.

Had these external constraints been waived, it is argued that the opportunities (poisoned gifts) offered by MICs to LACs as sources of transfer of technology, capital accumulation, expansion of market for exports products and acquisition of imports would have accelerated the transition of LACs from underdevelopment to economic development state faster than what MICs experienced in the early times of their economic development process. In a nutshell, the international environment in which LACs operate is a complete network that can either encourage or hold back their economic development. The merits of the model include the proposal for the right combination of domestic and international macro-economic policies to generate beneficial patterns of self-sustained economic growth and the identification of a common pattern in the process of economic development for almost all LACs. In spite of this, the model faced the following criticisms. The advocacy of the model to stress more on facts on ground (practical aspects) rather than theory tends to increase the risk of policymakers drawing wrong conclusions about a phenomenon based on exhibited patterns (declining share of labor force in agriculture over time leading to neglect of agricultural sector or appreciating role of higher education over time leading to development of advanced university system before majority of the population attained basic literacy, hence unfairness in resource allocation). Besides, most of the domestic and international factors that influence economic development are beyond the control of individual LACs.

The Solow growth model (SGM) is associated with Solow (1956) as an expansion of HDM by adding labor input and technology to the growth equation. According to Solow, economic growth of an economy depends on one or more of the three factors: increase in the stock of capital (savings and investments), increase in quantity and quality of labor (population growth and education) and technological improvements (labor saving, capital saving, labor augmenting, capital augmenting). The model explains that in the short run economies with higher rates of savings/investment (open/MICs) grow faster (in long run: growth is null) and tend to converge to higher per capita income levels as opposed to economies with lower savings rates (closed/LACs). The model exhibits diminishing returns to capital and labor separately but constant returns to scale to both jointly $(\alpha+\beta=1)$. Technological progress is regarded as the residual factor explaining long term economic growth and assumed its level to be determined exogenously, meaning that it is independent of all other variables. The Cobb-Douglass production function is used to explain this process of economic growth.

The 1960s were generally regarded as the years of independence for most LACs from colonial administrations. The growth in the number of independent countries and of a class of intellectuals in LACs over time triggered a sense of common destiny among the former colonies and raised a collective concern about the exploitative relations between them and the colonial administrations. This situation conditioned the rethinking of the theory of economic development along relationships between parties, hence the international dependence revolution models (IDRMs), which linked the underdevelopment condition of LACs to the perpetual dependent and dominant relationships between poor and rich countries through institutional, political and economic rigidities at both the domestic and international levels. The neo-colonial dependence model (NDM), false-paradigm model (FPM), and dualistic-development model (DDM) are prominent in this category.

The period 1960s-1980s ushered IDRMs as a replacement to LSMs. The models were a more radical and political movement that blamed the state of underdevelopment in LACs on the exploitative relationships between international and national powers, institutional and structural economic rigidities, and the existence of dual economies as well as dual societies in the world. As a result, they advocate for new policies such as diversification of employment opportunities, bridging income inequality gaps, eradication of poverty that conform to the realities of LACs rather than the application of sophisticated and imported models from MICs to LACs. The main argument of these theories is that external and internal institutional as well as political constraints are the main factors hindering economic development in LACs.

NDM is an outgrowth of Marxist thinking on the existence of unequal relationships between rich and poor countries of the world and unequal relationships between groups within the domestic setup of LACs. The existence of these types of relationships created a centre-periphery framework in which the periphery representing LACs is caught up in a dependence and dominance relationship with the centre represented by MICs that compromises development attempts of the poor countries. Furthermore, the entrepreneurs, landlords, military junta, salaried public officials and trade union leaders who constitute the ruling class in the periphery directly or indirectly serve the interest of the international capitalist system of inequality. This model views underdevelopment as an externally induced phenomenon designed by MICs and their representatives in the form of small but powerful elite groups in LACs to perpetuate the dependence and state of poverty of the latter in contrast to internal constraints underlined in previous models. As a result, it advocates for revolutionary campaigns of industrial nationalization and an inward-orientation in LACs to get rid of the international and 
domestic economic control of oppressors. Outspoken scholars of this stream include Baran (1957), Sunkel (1966), Franck (1967), Rodney (1972), dos Santos (1969, 1973), Galeano (1973), Amin (1974, 1976), Cardoso (1977), and Wallerstein (1980).

Opposed to the radical view of NDM that blames the economic underdevelopment of LACs on the domineering attitude of MICs is the moderate approach of FPM to economic development that attributes the state of persistent underdevelopment in LACs to the inappropriate piece of advice provided by international experts of MICs to LACs. These 'experts' offer sophisticated concepts, elegant models and complex technical methods of economics and other social sciences which do not match with LACs' realities. Because of institutional and structural factors such as high unequal ownership of land, disproportionate control over domestic and international financial assets and unequal access to credits, the policies offered to LACs often merely serve the vested interest of existing power structures at both domestic and international level since the required institutional and structural changes to facilitate the application of the models are undermined. Besides LACs leading university intellectuals, trade unionists, future high level government economists and other trained civil servants from MICs institutions having little or no really useful knowledge of their domestic realities are eager to implement MICs imported models which contradict with the peculiarities of their economies, whenever the opportunity is given to them. Furthermore, inappropriate or irrelevant Western concepts and models which emphasize much more on capital-output ratios, savings, investment ratios and growth rates of GDP are been taught in LACs higher institutions, thereby exposing students to the dynamism of MICs' economies at the expense of theirs. Easterly (2001), Stiglitz (2002) and Rodrik (2008) are the main advocates of this school.

The notion of dualism is embedded in both SCMs and IDRMs of economic development. Supporters of DDM like Boeke (1953) and Higgins (1956) argue that there is a coexistence and persistence of increasing disparities between different sets of conditions across the world. The world in general is cohabited by rich and poor countries at the same, while in LACs the society is characterized by the coexistence of dual structures in all spheres (rich and poor people living in the same area, modern and traditional techniques of production operating side by side, highly educated elites surrounded by masses of illiterate people, formal sector of economic activities competing with informal sector of economic activities, modern and traditional systems of education accommodated in same place). Furthermore, the model maintains that the dualistic conditions are chronic and not ephemeral for they are more than a temporary phenomenon that can be easily rectified or eliminated by time, adding that instead of the differences between the elements of superiority and inferiority to reduce, they are rather amplifying every year. Finally, it asserts that little or no efforts are made by the elements of superiority to pull up the elements of inferiority from their conditions. Ironically, continuous efforts are made by the elements of superiority to push down the elements of inferiority to a more advanced state of underdevelopment.

Lipton (1977) propounded the urban bias model (UBM) of economic development to argue that underdevelopment occurs in countries as a result of discrimination between urban centers and rural areas. Most often, more developmental projects and investments are intentionally done in urban centers contrary to rural areas; urban residents are given the opportunity to be more organized and politically powerful compared to rural dwellers. Furthermore, the model posits that trade protectionist policies and low food prices put in place adversely affect rural areas for farmers are not benefiting from these schemes, and the partiality against their areas induces them to migrate to urban centers to search for better job opportunities, thus leading to the crowding out of the informal sector employment and the increase in social evils in the cities. As a remedy to this, Streeten (1979) proposed the basic-needs approach (BNA) to economic development as a critique of the macro level of economic growth theories which were perceived as being partial in addressing the problem of economic development. Thus, BNA posits that for a country to experience economic development it must reduce mass deprivation, offer everyone the chance to live a full life by permitting people to meet basic needs of life such as food, shelter, education, clothing and medication; even thought the extent to which the reduction of mass deprivation is not specified.

\subsection{Economic Development Theories of the Period 1980s-1990s}

The period 1980s-1990s was dominated by the neo-classical counterrevolution or market fundamentalism model (MFM) which challenges the model of public ownership, planning and regulation of economic activities by the state. The theory emphasizes the important role of free markets, open economies and privatization of inefficient public enterprises to stimulate growth in the economy. The focal point of the theory is to explain that the state model has failed to bring economic development in LACs because of much government control of the economy sustained by wrong pricing policies, resources misallocation, corruption, and inefficiency in the socio-economic environment rather than exploitative internal and external factors as claimed by preceding theories (underdevelopment conditioned by exploitative activities of MICs and allies, dualistic nature of LACs, current 
patterns, or lack of capital accumulation in LACs). Citing the success stories of countries like Singapore, Taiwan and South Korea as specimen, these theories argue that market fundamentalism is the key to economic development for LACs. The leading scholars of MFM include Krueger (1978), Johnson (1971), Balassa (1971, 1982), Bhagwati (1978), Little (1982), Bauer (1984), and Lal (1985) who have extensively discussed the free market approach (FMA), public choice approach (PCA), and market-friendly approach (MFA) of MFM in their works.

On one extreme corner, FMA disregards the role government can play in fostering economic development in an economy. The main argument of the model is five folds. One, market (commodity, labor and money) alone is efficient and therefore should be allowed to allocate resources automatically. Two, competition is effective if not perfect. Three, producers are fully aware of what and how to produce efficiently. Four, information is perfect and almost free to obtain. Five, technology is free and nearly costless to absorb. According to FMA, the markets of developing economies are efficient enough to allocate resources in a manner that leads to sustained economic development. Above all, the imperfections that might exist in these economies have insignificant weight. Given these conditions, any intervention from the government in the economy will be distorting and destructive. On the other extreme end, PCA otherwise known as new political economy approach (NPEA) credits the government of doing nothing right and argues that the intervention of the government in the economy only leads to misallocation of resources and confiscation of private property, which in turn culminates in reduction in individual freedoms. Four points have been advanced to support these claims. One, politicians utilize public resources to strengthen and sustain themselves in power. Two, top government representatives take advantage of their positions to extract bribes (10\% contract commission) from citizens and run protected own businesses by the side. Three, the state uses the means at its disposal to track and intimidate potentials detractors (critics, opponents) and in extreme cases deprive them of their properties and jail them. Four, citizens use political influence of friends or relatives to obtain special benefits from government policies (import licenses). For the behavior portrayed by politicians, top government representatives, state and citizens who revolved around to achieve their own selfish interest through the use of power or authority of the government, PCA recommends minimal involvement of the government in economic activities of the economy as the best option that can facilitate economic development. At the fence, MFA acknowledges the existence of markets imperfections in LACs and the role the state could play in facilitating the operation of markets through market friendly interventions: creation of a favorable atmosphere for private enterprise and investment in social and physical infrastructures (roads, schools, health facilities...). Contrary to FMA and PCA, it admits that markets failures are rampant in LACs, especially in the areas of environmental outcomes and investment coordination, and also they are highly stained by lack of full information, absence of economies of scale in production, and shortage of incentives towards research and development (skill creation and learning). The significance of these three missing components paved way to the development of the endogenous growth model (EGM) and the coordination failure model (CFM) of economic development.

\subsection{Economic Development Theories of the Period 1990s-2015}

The early years of the 21 st century to date correspond to the period of contemporary models of economic development and underdevelopment (Coordination failure approach, Big push model, O-Ring model, Hausmann-Rodrik-Velasco decision tree model). These new theories draw on the arguments expressed by the classic theories of economic growth and economic development showing that development is possible but harder to achieve in LACs for today there are more obstacles than ever before on the path of economic development of LACs. The main argument of the new theories is that for a successful development to occur there must be an effective and efficient coordination or complementarities among the various stakeholders of the development process.

The MDGs agenda stresses on eight universal values that affect humanity and threaten its existence due to the multiplier effects of the globalization process of the world. Having perceived the dangers looming their economies in terms of unwanted migration, financial pressures on the state budget to cover social insurance benefits of migrants' children, unemployment grants to jobless people, and persistent needs for assistance in domestic affairs of LACs as a result of poor living conditions of people in these economies, MICs put in place MDGs agenda to reverse the trend of events; while giving the impression that they are concerned with the economic progress of the entire humanity on earth. The agenda proposes (i) to halve the rate of extreme poverty and hunger by providing full and productive employment and decent work for all, including women and young people between 1990 and 2015, (ii) to ensure that, by 2015, children everywhere, boys and girls alike, have completed at least a full course of primary education, (iii) to eliminate gender disparity in primary and secondary education by 2005 and in all levels of education by 2015, (iv) to reduce child mortality rate by $2 / 3$ between 1990 
and 2015. The other four remaining points of the agenda focus on (v) reducing the maternal mortality ratio by $3 / 4$ between 1990 and 2015 and offer universal access to reproductive health by 2015, (vi) combating and reversing the incidence of HIV/AIDS, malaria and other major diseases by 2015, (vii) ensuring environmental sustainability through reduction of loss of environmental resources, biodiversity loss, and $50 \%$ reduction of the proportion of people without sustainable access to safe drinking water and basic sanitation by 2015, and (viii) developing a global partnership for development through predictable, non-discriminatory trading and financial system with a commitment to good governance both nationally and internationally, holistic appreciation of debt problems to make debts of LACs bearable in the long term, provision of essential drugs at affordable rates to LACs, making available the benefits of information and communication technologies to LACs (United Nations Development Program [UNDP], 2014). Successes have been recorded around the globe with respect to the goals of the agenda but in general the targets are far from being achieved for LACs.

A perusal of the classic theories of economic growth and economic development reveals two opposite views of the state of underdevelopment in LACs. On one hand, the underdevelopment is perceived as an externally induced phenomenon owing to oppression of the international capitalist system and MICs. On the other hand, it is regarded as an internally induced episode mainly associated with poor policies and excessive government interventions of LACs. Also, given the pertinence of issues exposed by IDRMs and MFMs, one can infer that these theories are very much aware of the ideological views, economic conditions, and problems of LACs contrarily to the posture presented by SCMs and LSMs of economic growth as regards the LACs' realities. Yet, no single model of economic development can be proclaimed as universal and befitting in all situations because every LAC has different realities in spite of the general features common to all. In the end, one can argue that the theories so far examined are seemingly irreconcilable. All are significant and provide in one way or the other insights for the understanding of the dynamic process of economic development. Above all, each of the theories possesses strengths and weaknesses.

In a nutshell, IDRMs reject the claims of previous models of economic development so far studied to lay more emphasis on international power imbalances and the need for fundamental economic, political and institutional reforms at both the domestic and international levels. In extreme cases, these call for outright industrial nationalization hoping that the public ownership and control of assets may be a more effective strategy for poverty eradication, creation of employment opportunities, income inequalities reduction and improving the standard of living of the masses. In spite of the steps taken in denouncing and apportioning blames to suspected causes of underdevelopment of LACs, these theories give no insight on how economic development can be initiated and sustained. Also, the application of the models in some LACs such as China and India did not yield the expected results of economic development until they reopened their borders to rest of the world in 1978 and after 1990, respectively. Finally, the MDGs agenda did not also yield the expected results by the target dates. Many people in LACs are still faced with the problems of feeding, shelter, education, medication, accessing safe drinking water and sanitation services, and accessing electricity for the poverty and unemployment rates are still high and the income inequality gap between socio-economic groups is widening every day.

\section{Methodology}

LACs are usually regarded as countries from Africa, Asia and Latin America whose international economic transactions are guided by MICs. LACs are located between the $30^{\circ} \mathrm{N}$ latitude and $60^{\circ} \mathrm{S}$ latitude of the globe with a total area of 92490195 square kilometers $\left(\mathrm{Km}^{2}\right)$ corresponding to $61.5 \%$ of the world's total land (Hamond Incorporated, 1993, p. 210) and 3.158 billion people representing about $58.7 \%$ of the world total population in 1991 which is projected to 4.585 billion inhabitants or $63.8 \%$ of the total population of the world by 2010 (Kurian, 1992, p. 11). Based on these statistics, the population of LACs in 2015 can be approximated to 4.681 billion people or $65.14 \%$ of the 7.185 billion people living on the earth.

This paper mainly focuses on LACs. It heavily depends on secondary data and adopts analytical methods of data interpretation because of financial constraints and logistic support limitations to have a survey of LACs across the globe, which only international organizations such as IMF and WB can afford. The subject matter of the paper being a macro-economic issue, the authors acknowledge that not all aspects of it have been tackled to the appetite of all readers.

\section{Data Analysis and Discussion of Results}

This section encompasses the overall intricacies of economic transactions and transfer of funds between LACs and MICs. It is divided into trade linkages framework of LACs, financial ties and causes of balance of payments disequilibria of LACs, socio-economic development indicators of LACs and MICs, and effects of dependency on the economic development of LACs. 


\subsection{Trade Linkages Framework of LACs}

This sub-section examines trading relations, causes and consequences of exports instability. Also, it addresses the impact of adverse movements of in terms of trade.

\subsubsection{Trading Relations}

LACs are primarily known as primary products exporters and manufactured goods importers, whereas MICs are assumed to be endowed with technological, commercial, capital and socio-political predominance over dependent LACs. The form or nature of this predominance varies according to a particular historical moment and can therefore serve as a means of exploiting and extracting part of LACs local produced surpluses. Dependence is thus based on an international division of labor which allows industrial development to take place in some countries, while restricting it in others whose growth is conditioned by and subjected to the power centers of the world. The international division of labor between producers of agricultural products and producers of manufactured goods is a typical consequence of capitalist developments which necessarily assume the form of combined inequality among countries. This inequality arises from the characteristics of capital accumulation in which economic growth is based on the exploitation of the many by the few, and upon the concentration of ownership of the resources needed for social and economic development in the hands of the latter. The concentration of ownership of capital dominance in the world market and the monopoly of savings and investment in the hands of small natural groups are complementary elements in the establishment of a combined and unequal international system which the interdependent character increases as the commercial and industrial revolution bring about the need for the application of new technologies in production and communications. However, this does not imply that only LACs appear to be dependent; MICs are also dependent.

From 1933 till date, MICs underwent a gradual revival of their international economic activity by importing raw materials from LACs to supplement and sustain their economies. Even where self-sufficiency policies were rigorously pursued as in Germany, it was impossible to build up home economy without increasing imports of raw materials. As maintaining the volume of trade showed how closely interlinked the economic affairs of nations remained, changes in the way in which international trade was financed showed how far the old arrangements for setting those affairs has deteriorated. In the case of primary products, the value of current prices rose a little more than the volume though values in relation to gold were declining. But during the world depression period, the great fall in prices of agricultural produces enormously cheapened imports of industrial nations. The relative prices of exports and imports remained more favorable to MICs. It was as such possible for them to produce as much exports as solvency required without operating at full capacity. These conditions were in many ways frustrating because the primary products producing countries had for the time little opportunities to increase their exports earnings from foreign trade. These countries seem to be unfavorable fields for foreign investment, which might otherwise have helped to create bigger incomes. In addition, foreign transactions of most LACs are settled through MICs to whom LACs pay heavy taxes. Such is the case of former French colonies whose domestic currency is tied to the Euro through the French Franc to the extent that no direct foreign transaction can be undertaken and settled between a given former French colony and another MIC without the involvement and influence of France. Therefore, the major economic problem which LACs have to cope with in their international transactions is instability in their exports earnings. Notwithstanding, it can be observed that there exists a bi-directional dependency between LACs and MICs as advocated by the CAM of economic development, which MICs transformed to their advantage to sustain economic development and LACs surrendered to continue lingering in economic underdevelopment.

\subsubsection{Causes of Exports Instability}

Exports instability constitutes a problem to LACs' economic transactions since it affects their domestic incomes, consumption pattern, savings, investment levels, tax revenues, balance of payments (BOP) and capacity to import. And since imports are financed by exports receipts, an export shortfall will lead to a direct impact on LACs' ability to import. Here two elements appear paramount. One is the incidence of deviations from the trend of economic phenomena including prices mechanisms and exports earnings. Second is the mean amplitude of these deviations. In a free market, price variations occur in such a way that fluctuations in price of a commodity may be explained in terms of autonomous variations in either the demand for or the supply of that commodity. Short- run shifts in the demand curve for a product may occur as a result of a number of factors such as variation in the level or distribution of world income. The extent to which world income variations induce variations in the demand for a particular commodity highly depends on the income elasticity of demand for that commodity. Short-run fluctuations in the supply of commodities may on the other hand be caused by variations in weather condition and incidence of diseases. Another potential factor in the explanation of commodity price instability is 
the operation of cobweb type of adjustment systems. In some kinds of production, there is a considerable lag between production decisions being made and the resultant output coming onto the market. The basic notion behind the cobweb model is that, from a long term point of view, producers over respond to short run price movements. Most important among the factors that influence the problem of exports for which prices are subjected to, are MICs' decisions and will, but not market price mechanism. MDGs agenda in its eighth goal promised to offer a fair participation of LACs in international economic transactions to address the issue but achieved little, hence the perpetuation of unfavorable conditions for the take-off of economic development in LACs as denounced by NDM, FPM, and DDM of IDRMs.

\subsubsection{Consequences of Exports Instability}

Here, the interest is not on the implications of an export shortfall or excess, but instead the concern rests on the implication of instability about the trend of economic phenomena over a long period of time which incorporates positive and negative deviations. LACs' exports earnings constitute a problem to their economies, because the costs associated with exports shortfalls exceed any benefits derived from them or sometimes exports themselves involve exorbitant costs. In such situations a number of macroeconomic consequences result in the countries.

Consider a macro-economic model which involves foreign trade activities such as:

$$
Y=C+I+G+(X-M)
$$

Where,

Y: Level of national income;

C: Level of consumption;

I: Level of investment;

G: Government expenditure;

$\mathrm{X}$ : Exports;

M: Imports.

From Equation (1), it follows that an autonomous fall in exports will induce a multiplied reduction in income, the size of which depends positively on the multiplier. And since marginal propensity to consume (MPC) in LACs is expected to be larger than in MICs, it is obvious that the size of the multiplier is also large accordingly. Thus, a change in income will influence the values of the remaining variables. A fall in LACs' incomes will cause consumption, savings, government taxes, and private investment to fall. These changes will in turn influence the rate of economic growth, employment, people's standard of living and fiscal balance. On the other hand, when exports excess of LACs involve cost meaning that their international reserves generated an exports excess, a possible increase in domestic money supply will result. This occurs in long run supply where uncertainties about the future price of agricultural commodities deter the transition from subsistence agriculture to cash crops production. However, the main problem associated with uncertainty surrounding exports instability relates to development planning which at last depends on projected imports payments, debts servicing, capital flows and exports receipts. The lack of adequate institutions to manage, predict and forecast events in LACs to an extent account for their exports instability as explained by PDA of SCMs of economic development.

\subsubsection{Impact of Adverse Movements in Terms of Trade}

LACs' terms of trade are subjected to deterioration when the price of exports falls or that of imports rises or more generally if the price of exports falls relative to price of imports. Whatever the case, an adverse movement in terms of trade (TOT) of a particular LAC may have implications in its BOP, real income, people's standard of living, development, level of employment and rate of inflation. In LACs, both imports and exports are subject to inelastic demand which induce a worsening BOP situation. The effects of TOT deterioration on real income and standards of living depends on the initial causes of the deterioration. Then a fall in exports price brought about by an increase in efficiency will tend to result in an expansion in demand for exports and an increase in real income. But where the demand for imports is price inelastic, the volume of exports will have to be increased in order to pay for more highly priced imports so as to avoid deterioration in the balance of trade (BOT); if not domestic consumption of exportable goods and standards of living will fall. Thus, a deteriorating TOT implies a worsening BOT situation or falling standard of living or both. Similarly, a rise in imports prices will affect the level of employment and the rate of inflation. Other things being equal, unemployment will tend to rise and the prices of imports will shift expenditure away from domestic goods and services towards imported ones, causing cost-inflationary repercussions. 
Table 1 provides some statistics in relation to the magnitude of LACs' world exports and imports share in foreign transactions between 1951 and 1975. It shows that a substantial number of LACs have experienced adverse movements in their commodities' TOT, and have partly, as a result of the implied relative price changes between exports and imports, witnessed a deteriorating BOPs on current accounts. In addition to that, the demand for many LACs' exports had been adversely affected by both the technological progress in the supply of synthetic materials and low income elasticities of the demand that already exists. Between 1951 and 1960 LACs accounted for a falling share of both world exports and imports and experienced a generally deteriorating BOT position. During 1970s however, the LACs' share of exports increased quite significantly and their combined BOT moved into surplus. Although BOT position of oil exporting LACs did not indeed show a major improvement, BOT position of oil importing LACs shared a very substantial deterioration. And since there are more oil importing than oil exporting LACs, BOT position of most LACs assumed a deteriorating position over the period under consideration. Although the argument of CAM of economic development holds for MICs have limited options about the oil from LACs, the relationship between LACs and MICs is overshadowed by the domineering attitude of MICs that is vehemently condemned by IDRMs of economic development.

Table 1. LACs' share of world trade, 1951-1975

\begin{tabular}{|c|c|c|}
\hline Year & Share of Exports (\%) & Share of Imports $(\%)$ \\
\hline 1951 & 30.6 & 28.7 \\
\hline 1952 & 27.6 & 29.4 \\
\hline 1953 & 27.6 & 27.5 \\
\hline 1954 & 27.9 & 27.5 \\
\hline 1955 & 27.5 & 26.6 \\
\hline 1956 & 26.3 & 25.9 \\
\hline 1957 & 25.0 & 26.8 \\
\hline 1958 & 25.3 & 26.4 \\
\hline 1959 & 24.8 & 25.0 \\
\hline 1960 & 23.6 & 24.1 \\
\hline 1961 & 22.4 & 24.1 \\
\hline 1962 & 22.2 & 22.9 \\
\hline 1963 & 22.5 & 20.0 \\
\hline 1964 & 21.7 & 21.6 \\
\hline 1965 & 21.2 & 21.0 \\
\hline 1966 & 20.8 & 20.8 \\
\hline 1967 & 20.4 & 20.4 \\
\hline 1968 & 20.0 & 19.9 \\
\hline 1969 & 19.7 & 19.4 \\
\hline 1970 & 19.2 & 19.4 \\
\hline 1971 & 19.4 & 19.4 \\
\hline 1972 & 19.5 & 18.5 \\
\hline 1973 & 20.2 & 18.6 \\
\hline 1974 & 28.2 & 20.7 \\
\hline 1975 & 25.5 & 23.5 \\
\hline
\end{tabular}

Source: International Financial Statistics by IMF, adapted from Bird (1978, p. 80).

\subsection{Financial Ties and Causes of Balance of Payments Disequilibria of LACs}

The focus of international finance rests on the issue of harmonizing world economic transactions between countries to stabilize the international economy. The provision for such an atmosphere calls for the degree of acceptance and reliability nations' domestic currencies can achieve in settling economic transactions across 
boundaries. The question as to which currency or money can be accepted in world transactions among countries due to some problems associated with the roles of inside monies and near monies finds its answer in the historical evolution of money, right from the pre-World War I period to 1945 when US\$ became dominant and started performing international roles in world economies. It was considered a vehicle for operating transactions such as settling between non-banks/non-bank firms, retail foreign exchange market in which firms deal with banks, medium of exchange since 1970 in relation to other currencies, and an intervention currency through which central banks intervene in the existing private interbank markets. With all these responsibilities, anything that affects the US future markets is susceptible to affect the international finance arena and vice versa.

The importance of bilateral settlement of international payments was openly recognized as a way of expanding world trade since international concerns are subject of national considerations of each country in the world. But no matter what the disparities between world economics internal policies, there exists an international economy sharing a considerable amount of common experience. The temporary cessation of international investments during the former economic depression of 1930s left untouched the intricate network of indebtedness on which world production and trade depended, and the persistent growth of bilateral settlements restricted the volume of trade moving in some channels thereby multiplying from one end to another with less receipts realized. Most LACs' domestic currencies are either pegged to the US\$ or linked directly to their former colonial power domestic currency. The problems of reconciling LACs' dependency with different national economic and monetary policies directed by MICs' trend of economic performance remained unsolved. MICs have for long learnt a good deal about how monetary policies could be used to shield them from undesired effects of external depression, but have done little to lessen the changes of depression occurrence in the rest of the world. LACs had seen their commodities' market collapsing due to the extreme vulnerability of their position in the existing state of international specialization.

Against this background, LACs became anxious and eager to remedy their position or condition in the most obvious possible way through diversification of their economies with some industrialization. But unfortunately for them the capital materials and inputs are lacking coupled with the cessation of international investment which meant that required funds or finance cannot be obtained from their trading MICs partners. The division of the world through deliberate actions into one great creditor and a host of impoverished debtor completely transformed the position of international trade and finance. Many LACs had incurred such greatly increased financial obligations, while their capacity to meet them had deteriorated, that they could not quickly resume their old place in commerce. LACs were forced to seek whatever assistance needed from outside under multitudinous stringent controls over their trade and finance such that even when they import from trading partners other than the country to which their domestic currency is tied, they have to pay import taxes.

From 1945 to 1947, that is, at the beginning of IMF operations, provisions were made to avoid underside effects of the multiplier effect during short-run period. The intention of making funds available to countries suffering from temporary BOP deficiencies was aimed at restoring and maintaining a stable exchange rate between currencies so as to prevent the need for imposing exchange rate restrictions or currency devaluation (appreciation) on economies-each of which having a multiplying effect on international financial and trading activities. Besides, the international effects of any country's monetary policies may be transmitted by some or all of the economic links between countries. However, when two or more economies assume some economic ties, the job of tracing monetary repercussions becomes correspondingly very complex. A common feature of all international financial transactions between countries' foreign exchange market conditions is the presumption that the US\$ plays the passive key currency role in the world foreign exchange market. As such the effectiveness of monetary policy in open economies depends on the sensitivity of investors to differences in interest rates on similar assets dominated in several currencies. Domestic monies and foreign monies are often substitutes of each other. Likewise, domestic securities and foreign securities are assumed to be perfectly substitute commodities. Thus, it is impossible for any central bank to follow an independent monetary policy either under pegged exchange rate or floating exchange rate without becoming the central bank of the world at large. But abstracting from the influence of size, it is obvious that LACs will tend to demand for more of reserve assets from international financial institutions than MICs do since their BOPs are subjected to greater instability. This in turn implies a greater incidence of deficits since the cost of adjustment too is higher than observed in the rest of the world. In short, the opportunity cost of holding reserves is lower in LACs. Logically, it seems very sound to argue that LACs experience greater BOPs instability and higher cost of adjustment compared to MICs, because of the nature of their imports in fostering economic growth. Again, a critical look at the financial relations between MICs and LACs reflects the dependency phenomenon in favor of the former that IDRMs of economic development are opposing. 
Being either deficit or surplus such BOP is said to be in disequilibrium. BOPs of LACs are mostly of deficit type and this condition is basically caused by monetary phenomena resulting from inter-economic relations or transactions between countries. Meanwhile, disequilibrium in BOPs can also arise from structural setups. Inappropriate monetary policy in one country can influence the economic conditions of that country negatively first, before transmitting its germs to its trading partners. Creation of money at a rate faster than the rate at which real domestic output is growing will tend to host inflation and generate BOP deficit. Conversely, LACs' exports which are predominantly primary products, have lower income elasticity of demand, whereas imports' income elasticity is relatively higher - a fertile ground for the breeding of a deteriorating BOP position, hence the need for LACs to exploit the proposals of FTM, MFMs, and IDRMs of economic development.

\subsection{Socio-Economic Development Indicators of LACs and MICs}

Table 2 displays selected socio-economic development indicators of some LACs and MICs. It shows that in 2012 the average gross national income (GNI) per head for LACs translates to $\$ 3092$ billion against $\$ 66202$ billion for MICs, which is roughly 21 times the average GNI of LACs. Also, the average rate of unemployment of the labor in LACs as at 2012 stands at $17 \%$, representing approximately 5 times the average rate of unemployment of $3.6 \%$ for MICs. As regards political stability rating on a scale of -2.5 to 2.5 units, the average score of -1.04 units for LACs is negatively skewed standing at -1.46 units (roughly $42 \%$ ) to the worst score limit of -2.5 units, whereas the average score of 1.25 units for MICs indicates a positive skew standing at 1.25 units (roughly 50\%) to the best score limit of 2.5 units. About the perceived level of corruption in a cohort of 175 countries around the world on a scale of 0 to $100 \%$ in 2014, the average score for LACs approximates to $32 \%$ as opposed to roughly $81 \%$ for MICs. This performance indicates that the socio-economic environment of MICs is 2.53 times corruption-freer than that of LACs.

A careful observation of the performance of the selected socio-economic development indicators reveals that all are in red in LACs, while in MICs they are all in green, thus portraying two opposite situations with a wide gap between the living environment of LACs and MICs. The gap between the two living environments is due to the perpetration of socio-economic evils such as greed, favoritism, pride, and misplacement of priorities by the elites in one hand, and fatality and poverty of the masses on the other hand in the case of LACs and the opposite of these evils plus the continuous search for improvement of any current situation in the interest of the society in the case of MICs. The attitudes of MICs promote proper self-development of people, accelerate the building process of a nation, and create confidence and reliability in and between countries. These values are almost eroded in LACs.

Table 2. Selected socio-economic development indicators of LACs and MICs

\begin{tabular}{llcccc}
\hline \multicolumn{1}{c}{ Parameter } & \multicolumn{3}{c}{ Socio-economic Development Indicator } \\
\hline Class & Country & $\begin{array}{c}\text { Gross National Income per } \\
\text { Head in 2012* } \\
\text { (Billion US\$) }\end{array}$ & $\begin{array}{c}\text { Unemployment Rate of Labor } \\
\text { Force in 2012* }\end{array}$ & $\begin{array}{c}\text { Political Stability in } \\
2012^{* *}\end{array}$ & $\begin{array}{c}\text { Corruption Index } \\
\text { in 2014*** }\end{array}$ \\
& & $(\%)$ & $(-2.5$ to 2.5 Units) & $(\%)$ \\
\hline South Africa & 7460 & 25 & -0.00 & $44(67)$ \\
Algeria & 5020 & 10 & -1.34 & $36(100)$ \\
LACs & Sudan & 1500 & 15 & -2.27 & $11(173)$ \\
& Mauritania & 1110 & 31 & -1.13 & $30(124)$ \\
& Liberia & 370 & 4 & -0.47 & $37(94)$ \\
& Average (a) & 3092 & 17 & -1.04 & 31.6 \\
\hline Qatar & 88350 & 1 & 1.21 & $69(26)$ \\
Norway & 67450 & 3 & 1.31 & $86(5)$ \\
MICs & Luxembourg & 60950 & 5 & 1.34 & $82(9)$ \\
Australia & 59260 & 5 & 1.40 & $80(11)$ \\
Switzerland & 55000 & 4 & 1.25 & $86(5)$ \\
Average (a) & 66202 & 3.6 & & 80.6 \\
\hline
\end{tabular}

Source: * World Bank (2014); **Quandl (n. d.); ***Transparency International (2014); (a) Authors.

Note. Figures in brackets in the last column of perceived level of corruption index represent the raking of countries in a cohort of 175 countries around the world. 


\subsection{Effects of Dependency on the Economic Development of LACs}

Drawing from the analysis of the trading relations and financial ties between LACs and MICs, and the status of socio-economic development indicators of LACs, a series of implications for the economic development of LACs can be underlined. The persistent disequilibria in BOP affect the possibility of achieving a sustainable economic development for economic growth may stagnate; unemployment and poverty rates may amplify; and income inequality gap may broaden in the economies, thus leading to worse living conditions of the masses. The poor performance in the fight against corruption reflected in the low percentage level of corruption index in LACs may shrink investment opportunities due to lack of confidence of private investors in the institutions that are expected to offer a conducive business environment to potential stakeholders of the private sector. Furthermore, the corruption phenomenon may impinge on the execution of infrastructural development projects by the government for revenues that were supposed to accrue to government end up in people's pockets. The low per capita gross national income reflects a low level of productivity of the main sectors of economic activities and the existence of a large sector of informal economic activities that escape government accounting in LACs. The negative value of political stability across LACs explains the extent to which good governance is poor in these countries. In fact the minimum required conditions to facilitate economic development are abused in LACs because the opportunities for self-actualization of people are confiscated by few individuals who hang on to power for decades without offering better living conditions to their citizens but instead spare no efforts in satisfying the needs and requests of their counterparts in MICs who undertake to arm and protect them against any attempt to alter the established order. From the colonization period to 1980s, the dependency model between LACs and MICs procured enormous advantages to MICs in terms of industrial raw materials and income generation that sustained their economic development. On the contrary, the model offered a dismal situation to LACs as the economic and human resources needed for the building of the economies were surrendered and extinct by the elites to keep power in their hands. However across time, the love and obsession for power engaged the elites in LACs into conflicts which degenerated into civil wars as witnessed in Angola (1975-2002), Burundi (1993), Central African Republic (2002-2014), Chad (1960-1990), Côte-d'Ivoire (2002-2007), Democratic Republic of Congo (2002-2007), Kenya (2008), Liberia (1999-2003), Nigeria (1967-1970), Rwanda (1994), Southern Sudan (2013) or popular protests as experienced in Cameroon (1990, 2008), Egypt, Libya, and Tunisia (2011). The havocs of these social deviations have a direct bearing on the economic development of affected countries for all the material and human losses incurred have to be replaced or reconstituted with colossal means through borrowing from MICs, IMF or WB, thereby reinforcing and perpetuating the dependence of LACs on MICs. The continued political and economic association of former colonies of LACs to colonizing nations of MICs weakens the ability of LACs to draw a societal model reflective of their values and the power to design their own monetary policies, thus creating a vicious circle of dependency of LACs on MICs that complicates the path of economic development for LACs. Most French speaking LACs are caught into that cobweb. All put together, it becomes evident that LACs need to ponder on the submissions of FTM, HDM, SCM, BNA, MFMs, and IDRMs of economic development before aspiring to economic progress.

\section{Conclusion and Recommendations}

The complementarily between LACs and MICs in economic transactions (flow of goods and services and transfer of funds) is a precondition to economies interdependence. However, in the case of LACs, the degree of dependency assumes a wider scope ranging from high demand for capital goods and services to severe subjugation in financial matters. Owing to recent development in the history of world economic crisis, it is observed that world changes in 1970s and particularly price increases in oil demonstrated that the problems created by adverse movements in the TOT are not solely the concern of LACs. Nonetheless, LACs do tend to face more severe problems in adjusting to adverse effects of their TOT. Imports are more likely to be vital, but LACs appear to be unable in the short-run at least, to supplement them by domestic production. Beside, factors of production may be relatively immobile so that LACs find it difficult to shift resources from production for the home market into the production of exports or imports substitutes. In short this presupposes that for oil importing LACs, it is either the rise in imports prices or the tendency of demand for exports to stagnate or fall that causes their economic TOT to deteriorate. The strength of most LACs' domestic currencies in international settlements is lower than that of MICs. The purchasing power parity favors more MICs at the expense of LACs. This makes LACs to lag behind MICs to seek for aid, assistance and debts rescheduling from time to time. And above all LACs' monetary policies (where existing) are inconsistent with their domestic considerations. The pattern of MICs' monetary policies influences LACs' monetary policies, making them weaker and vulnerable in front of the stabilization argument. Thus, though increasingly acting as engines of progress for MICs with the main economic activity flowing from North (MICs) to South (LACs) with considerable adverse effects on LACs, it 
was observed that LACs accounted for nearly 30\% of the increase in world trade between 1980-1990 implying that an extra percentage in their growth rate added about 0.1 to $0.2 \%$ to the growth rate of MICs (Kurian, 1992, pp. xiii-xiv). Finally for LACs, the concept of interdependence assumes a particular significance for it seems as the most powerful argument they can advance for the greater involvement of MICs in their economic advancement. In other words, LACs view all countries in the world as developing and dependent. And it is this order of dependence and development that makes economic distortions originating from one end to reach the other, hence the call for continuous dialogue between the MICs and LACs as a basis of sustenance for equality and mutual respect between them.

For LACs to align or realign themselves on the path of moderate dependency in their international trade and financial position to attain economic development, an inner outlook appears paramount. They must view their present condition as a challenge rather than a myth. By doing so they should be able to consider their differences on which new ramifications can be built as to how their exports earnings would fetch themselves their real worth. Also, the traditional links between them and their former colonial masters should be loosen, meaning that not necessarily their domestic currencies be directly quoted or linked to colonial masters' currencies. This, if put into consideration can lessen the burden of tax paid against commodities imported even from partners other than their former colonial masters. Besides, more freedom in their economic transactions and monetary policies can bloom up. Furthermore, LACs should try to make their socio-economic living environment conducive and attractive to people's aspirations in the society irrespective of their background. Finally, the need to completely reverse the former socio-economic and political dome between LACs and MICs should be embraced without any delay and reservation through profound structural changes and implementation of the ideas of IDRMs and MFMs.

\section{References}

Amin, S. (1974). Accumulation on a world scale. New York: Monthly Review Press.

Amin, S. (1976). Unequal development: An essay on the social formations of peripheral capitalism. New York: Monthly Review Press.

Balassa, B. (1971). The structure of protection in developing countries. Baltimore, USA: Johns Hopkins Press.

Balassa, B. (1982). Development strategies in semi-industrial economies. Baltimore, USA: Johns Hopkins Press.

Baran, P. A. (1957). The political economy of growth. New York: Monthly Review Press.

Bauer, P. T. (1984). Reality and rhetoric: Studies in the economics of development. London: Weidenfield \& Nicolson.

Bhagwati, J. N. (1978). Anatomy and consequences of exchange control regimes. Cambridge: Ballinger Publishing Company.

Bird, G. (1978). The international monetary system and the less developed countries. London: Macmillan.

Boeke, J. H. (1953). Economics and economic policy of dual societies. New York: International Secretariat, Institute of Pacific Relations.

Cardoso, F. H. (1977). The consumption of dependency theory in the United States. Latin American Research Review, 12(3), 19-20.

Chenery, H. B. (1960). Patterns of industrial growth.American Economic Review, 50(3), 624-654.

Chenery, H. B., \& Syrquin, M. (1975). Patterns of development: 1950-1970. New York: Oxford University Press.

Chenery, H. B., \& Taylor, L. J. (1968). Development patterns among countries and over time. Review of Economics and Statistics, 50(4), 391-416. http://dx.doi.org/10.2307/1926806

De Monchrétien, A. (1891). Les tragedies de Monchrétien. Paris: Nourritet Cie.

Domar, E. D. (1947). Expansion and employment.American Economic Review, 37(1), 34-45.

Dos Santos, T. (1969). The crisis of development theory and the problem of dependence in Latin America. Siglo, 21, 36-54.

Dos Santos, T. (1973).The crisis of development theory and the problem of dependence in Latin America. In H. Bernstein (Ed.), Underdevelopment and development: The third world today (pp. 57-79). New York: Penguim Books.

Easterly, W. R. (2001). The elusive quest for growth: Economists'adventures and misadventures in the tropics. Cambridge: Massachusetts Institute of Technology Press. 
Fei, J. C. H., \& Ranis, G. (1964). Development of the labour surplus economy: Theory and policy. Homewood, ILL: Richard Irwin.

Franck, A. G. (1967). Capitalism and underdevelopment in Latin America. New York: Monthly Review Press.

Galeano, E. (1973). Open veins of Latin America.New York: Monthly Review Press.

Hamada, K. (1974). Alternative exchange rate system and the interdependence of monetary policies. In R. Z. Aliber (Ed.), National monetary and international financial system (pp. 13-48). London, Chicago: University of Chicago Press.

Hamond Incorporated. (1993). Oxford Hamond atlas of the world (p. 210). Oxford: Oxford Press.

Harrod, R. F. (1939). An essay in dynamic theory. The Economic Journal, 49(193), 14-33. http://dx.doi.org/10.2307/2225181

Higgins, B. (1956). The dualistic theory of underdeveloped areas: Economic development and cultural change. Chicago: The University of Chicago Press.

International Monetary Fund [IMF]. (2014). World economic outlook: Legacies, clouds, uncertainties. $\begin{array}{llllll}\text { Washington: } & \text { IMF. } & \text { Retrieved } & 12 & \text { April } & 2015\end{array}$ http://www.imf.org/external/pubs/ft/weo/2014/02/pdf/text.pdf

Jevons, W. S. (1871). The theory of political economy. London: Macmillan.

Johnson, H. (1971). A word to the third world: A western economist's frank advice. Encounter, 37, 3-10.

Jorgenson, D. W. (1961). Development of a dual economy. Economic Journal, 61, 309-334. http://dx.doi.org/10.2307/2228770

Keynes, J. M. (1936). The general theory of employment, interest, and money. Cambridge: Cambridge University Press.

Krueger, A. O. (1978). Foreign trade attempts and economic development: Liberalization attempts and consequences. Cambridge: Ballinger Publishing Company.

Kurian, G. T. (1992). The atlas of the third world (2nd ed.). New York: Facts on File (xiii-xiv-Preface).

Lal, D. (1985). The poverty of 'development economics. Cambridge: Harvard University Press.

Levitt, K. P. (1989). Linkages and vulnerability: The debt crisis in Latin America and Africa. In B. K. Campbell (Ed.), Political dimension of the international debt crisis (p. 15). London: Macmillan.

Lewis, W. A. (1954). Economic development with unlimited supplies of labour. The Manchester School, 22(2), 139-191. http://dx.doi.org/10.1111/j.1467-9957.1954.tb00021.x

Lipton, M. (1977). Why poor people stay poor: Urban bias in world development. London: Temple Smith Press.

Little, I. (1982). Economic development: Theories, policies, and international relations. New York: Basic Books.

Malthus, R. T. (1798). An essay on the principle of population. London: Macmillan.

Marshall, A. (1890). Principles of economic: An introductory volume. Canada, Rod Hay's Archive for the History of Economic Thought of MacMaster University. Retrieved 11 February 2015 from https://www.marxists.org/reference/subject/economics/marshall/

Menger, C. (1976). Principles of economics. Auburn, Alabama, USA: Ludwig von Mises Institute. Retrieved 13 March 2015 from http://mises.org/sites/default/files/Principles\%20of\%20Economics_5.pdf

Mun, T. (1621). A discourse of trade from England unto East Indies. London: Nicholas Okes for John Pyper.

Mun, T. (1664). England's treasure by forraign trade or the balance of our foreign trade is the rule of our treasures. London: Printed by J. G. for Thomas Clark.

Pieterse, J. N. (2010). Development theory: Deconstructions/reconstructions. London: Sage Publications. http://dx.doi.org/10.4135/9781446279083

Quandl. (n.d). Estimated political stability by country. Retrieved 12 April 2015 from https://www.quandl.com/society/estimated-political-stability-by-country

Ranis, G., \& Fei, J. C. H. (1961). A theory of economic development. American Economic Review, LI(3), 533-565.

Ricardo, D. (1817). On the principles of political economy and taxation. London: John Murray. 
Rodney, W. A. (1972). How Europe underdeveloped Africa. London: BogleL'Ouverture.

Rodrik, D. (2008). The real exchange rate and economic growth. Brookings Papers on Economic Activity, 2, 365-412. $\quad$ Retrieved $13 \quad$ March 2015 from http://www.brookings.edu/ /media/projects/bpea/fall-2008/2008b_bpea_rodrik.pdf

Rostow, W. W. (1960). The stages of economic growth: A non-communist manifesto. Cambridge: Cambridge University Press.

Smith, A. (1776). An inquiry into the nature and causes of the wealth of nations. Reprinted in 1976, United Kingdom: Clarendon Press. http://dx.doi.org/10.1093/oseo/instance.00043218

Solow, R. M. (1956). A contribution to the theory of economic growth. The Quartely Journal of Economics, 70(1), 56-94. http://dx.doi.org/10.2307/1884513

Steuart, J. (1767). Inquiry into the principles of political economy. Canada: Rod Hay's Archive for the History of Economic Thought of MacMaster University. Retrieved 11 February 2015 from https://www.marxists.org/reference/subject/economics/steuart/index.htm

Stiglitz, J. E. (2002). Globalization and its discontents. New York: W.W. Norton \& Company.

Streeten, P. P. (1979). A basic-needs approach to economic development. In K. P. Jameson, \& C. K. Wilber (Eds.), Directions in economic development. Notre Dame: University of Notre Dame Press.

Sunkel, O. (1966). The structural background of development problems in Latin America. Deutschland: Weltwirtschaftliches Archiv, 97(1), 22.

Thirlwall, A. P. (1999). Growth and development with special reference to developing economies. London: McMillan Press Ltd.

Todaro, M. P., \& Smith, S. C. (2009). Economic development. London: Addison-Wesley.

Transparency International [TI]. (2014). Corruption perceptions index 2014. Berlin: TI. Retrieved 08 April 2015 from http://www.transperanct.org

United Nations Development Program [UNDP]. (2014). The millennium development goals: Eight goals for 2015. New York: UNDP. Retrieved 09 April 2015 from http://www.undp.org/mdg/

Wallerstein, I. M. (1980). The modern world-system II: Mercantilism and the consolidation of the Europeanworld economy (pp. 1600-1750). New York: Academic Press.

Walras, L. (1899). Elements of pure economics or the theory of social wealth. Homewood, ILL: Richard Irwin.

World Bank. (2014). World development indicators 2014. Washington: World Bank. Retrieved 12 April 2015 from http://data.worldbank.org/sites/default/files/wdi-2014-book.pdf

\section{Copyrights}

Copyright for this article is retained by the author(s), with first publication rights granted to the journal.

This is an open-access article distributed under the terms and conditions of the Creative Commons Attribution license (http://creativecommons.org/licenses/by/3.0/). 